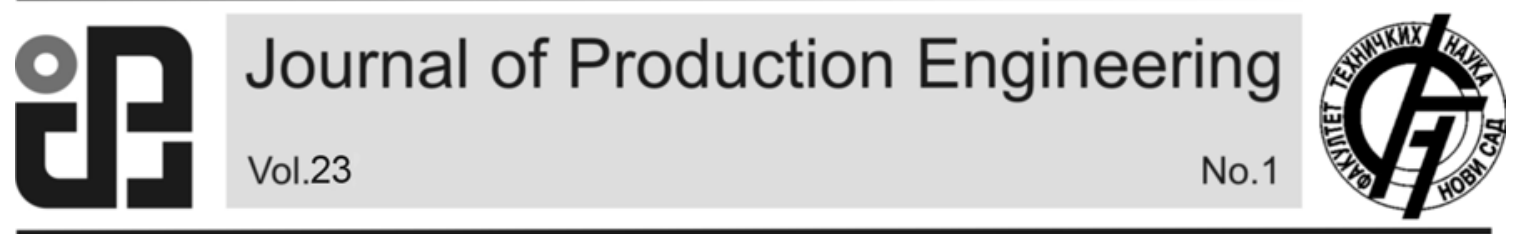

JPE (2020) Vol.23 (1)

Tóth, L., Akylbek, U., Cservenák, Á., Bányai, T., Illés, B., Tamás, P.

Original Scientific Paper

\title{
PRODUCT IDENTIFICATION PROBLEMS USING INDUSTRY 4.0 TECHNOLOGIES
}

Received: 26 March 2020 / Accepted: 11 June 2020

\begin{abstract}
Industry 4.0 technologies can improve not only the performance of manufacturing and assembly processes, but also the efficiency of related logistic operations can be increased. Within the frame of this article we show a system for identifying product mixing problems using Industry 4.0 technologies. The identification of loading unit building equipments and products is based on RFID tags. We used Excel format database file to hold the binding matrix of the products. We have developed a software that controls our industrial IF30 RFID reader. Our software performs a product mix detection test as well.
\end{abstract}

Key words: RFID, product identification, product mixing problems, Industry 4.0

Problemi s identifikacijom proizvoda pomoću tehnologije 4.0. Tehnologije industrije 4.0 mogu poboljšati ne samo performanse proizvodnih i montažnih procesa, već i efikasnost povezanih logističkih operacija. U okviru ovog rada prikazan je sistem za identifikaciju problema sa mešanjem proizvoda pomoću tehnologije 4.0. Identifikacija opreme i proizvoda za izgradnju uređaja za utovar temelji se na RFID oznakama. Korišćena je datoteka baze podataka eksel formata za održavanje matrice vezivanja proizvoda. Razvijen je softver koji kontroliše industrijski IF30 RFID čitač. Predstavljen je softverkoji takođe obavlja test detekcije miksa proizvoda.

Ključne reči: Identifiacija radio frekvencije, identifikacija proizvoda, problemi sa mešanjem proizvoda, Industrija 4.0.

\section{INTRODUCTION}

Radio Frequency Identification (RFID) can be traced back to the time of World War II. British aircraft transmitted their own ID back to the enemy-friendly detection system when receiving the radar signals [1]. Since then, the system has been further developed, its size miniaturized and its operation optimized. Today, RFID systems are available in low frequency (LF), high frequency (HF), ultra-high frequency (UHF) and microwave options. Active tools have been developed to increase read/write distance. RFID technology has also been applied in the field of logistics, commerce, pharmaceuticals, animal husbandry, transportation and also service industries. It can also be used in logistics systems for product identification, tracking and product composition determination.

The theory and application of RFID technology has been researched for more than 70 years. Russian physicist Leon Theremin was the first person, who created the first RFID device in 1946 [2].

RFID technology is used in various fields of industry and services. RFID implementation has a great impact on flexibility, quality, efficiency and availability of logistic processes because human error consequences can be mitigated for example in general cargo handler logistics [3]. The quality of logistics operation can be increased with the application of identification technologies because information processing and anomaly mining can be performed based on cloud, fog or edge technologies [4]. RFID applications can support the operation of complex logistic and material handling processes and scheduling, assignment and routing problems can be solved with more efficiency, especially by using of heuristic and metaheuristic solutions in the case of NP-hard problems [5].

A special field of application of RFID technologies is the healthcare, where patient and medical asset operation management can be supported with Industry 4.0 technologies and related logistic operations, like medical logistics sorting systems can be improved [6-8]. Wireless sensor systems and RFID monitoring systems in airport logistics validate the importance of this technology in the field of security [9]. RFID technologies are used not only in the case of traditional manufacturing systems, but they can be applied in the case of hybrid or cloud solutions [10]. The integration of RFID-wireless sensor networks supports decision models and optimization of logistics systems operations [11]. Interesting applications can be found in the field of academic, logistics, passenger transport [12] or animal intelligent logistics management [13]. Implementation of an RFID-based sequencing-error-proofing system for automotive manufacturing logistics shows the impact of this technology on quality related processes, like total quality management, quality of products and processes [14].

In this paper, we present a system developed to identify product mixing problems using industry 4.0 tools. With the help of the developed system, the product composition of unit loads can be checked, thus possible product mixing problems can be revealed.

\section{PROBLEM DESCRIPTION}

In practical life, controlling the contents of unit loads often requires significant human resources. Such a case could be for instance checking the composition of unit loads stored in intermediate operations warehouses, warehouses, receiving areas. The inspection checks the 
type and quantity of products stored and eliminates any defects (more or less products, non-compliant products, etc.). The system presented in the paper has been developed in order to reduce the manual dismantling of unit loads and the subsequent control operations.

\section{ELEMENTS OF THE DEVELOPED SYSTEM}

The integrated logistics system developed in the laboratory of the Institute of Logistics of the University of Miskolc has manual and fixed position RFID readers (Figure 1), antennas with different gains (Figure 2), selfadhesive, printable and environmentally resistant, plastic-enclosed labels (Figure 3).

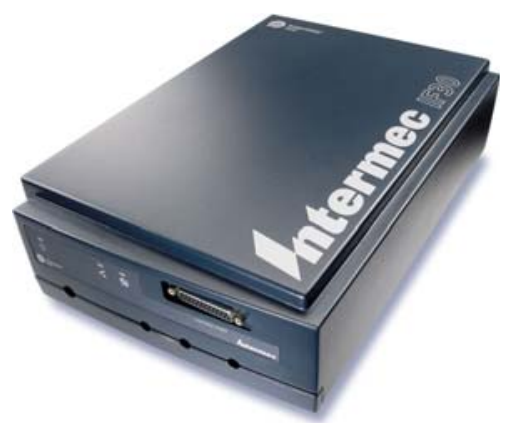

Fig. 1. Desktop RFID reader
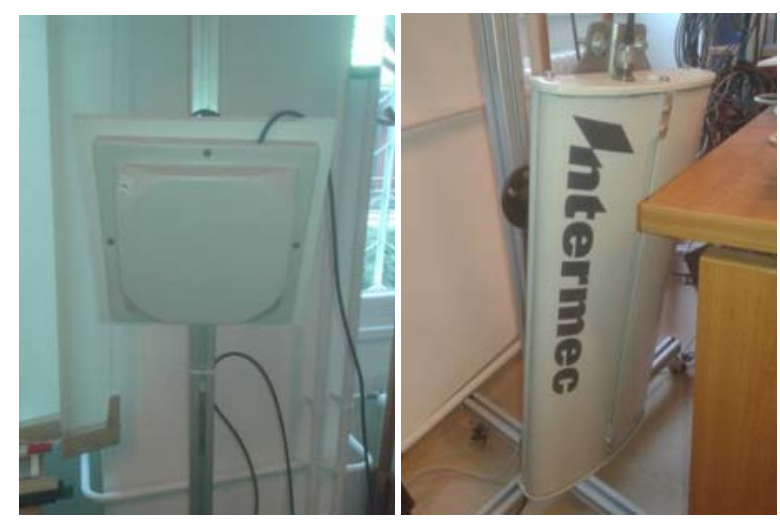

Fig. 2. URH antennas
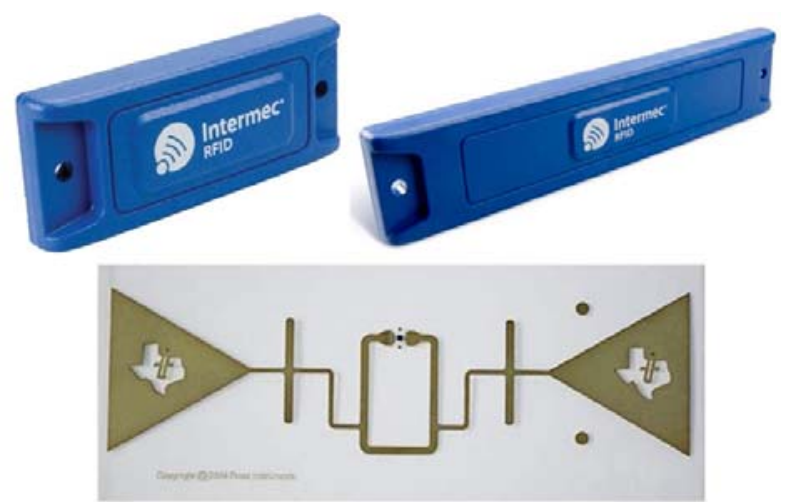

Fig. 3. IT65 small and large passive RFID tags and Texas Instruments Gen2 tag [15]

Four RF antennas can be connected to the IF30 Intermec UHF RFID reader. The device has general purpose I/O ports (GPIO), an Ethernet network connector, and an RS232 configuration port. Supported RFID communication standards: EPCglobal UHF Gen
2, ISO 18000-6b, ISO 18000-6c, Philips Version 1.19, Fairchild G1. Its operating temperature range meets industry requirements $\left(-20{ }^{\circ} \mathrm{C}\right.$ to $\left.55{ }^{\circ} \mathrm{C}\right)$, and its frequency range is 865,869 and $915 \mathrm{MHz}$

Self-adhesive RFID tags were affixed to the unit load devices (ULD). Additional boxes were placed in the boxes (Figure 4), which contained additional RFID devices. We recorded the binding of each product in an Excel format database (Figure 5). We have developed software that, on the one hand, controls our industrial IF30 RFID reader for product identification and, on the other hand, performs a product mixing detection test based on the scanned IDs and the database.

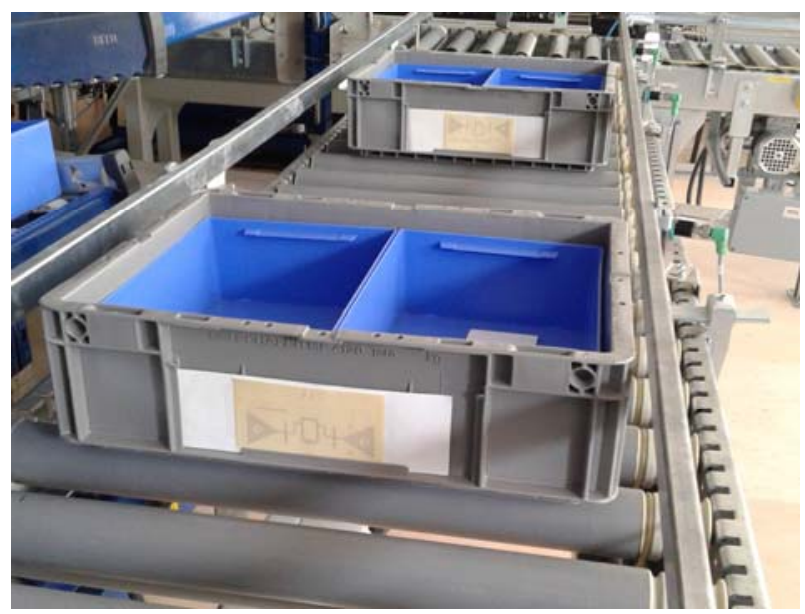

Fig. 4. RFID tagged ULD and accessories

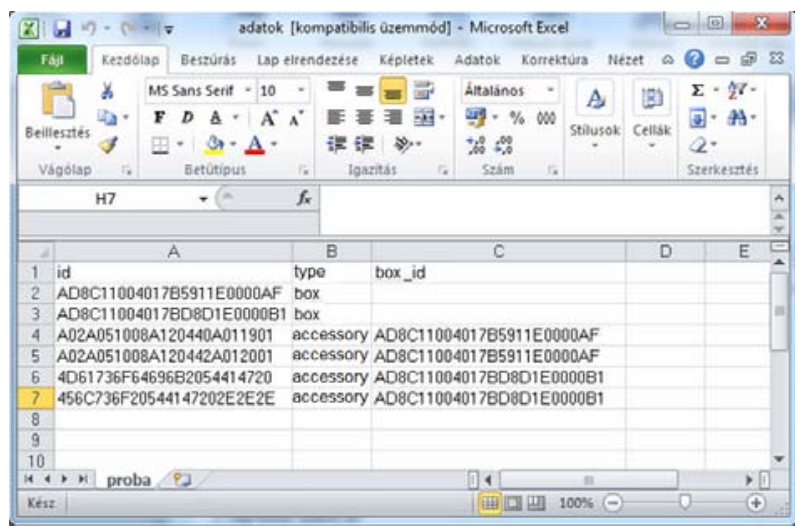

Fig. 5. Excel-based application

\section{OPERATION OF THE DEVELOPED SYSTEM}

Product IDs should be stored in a database. The computer that examines the product composition can use the identifiers in this database to determine whether the unit load is correct or defective. CSV (CommaSeparated Values), Excel or MS Access file format can be used as a database. The Excel file format have been used for easier editing.

Our database actually contains the product binding matrix. The first column lists the IDs of each tag (Figure 6). These are unique identifiers. The second column shows the type of products. In our present system, two types of identification types are defined. These can be boxes or accessories. In the third column of the database, for the accessory type identifiers, it is specified to which box it belongs. 


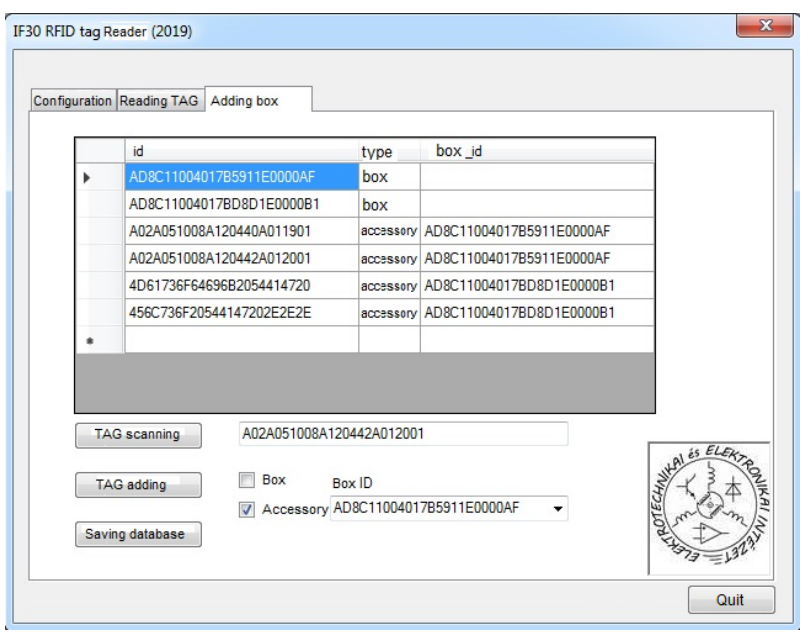

Fig. 6. Application data entry page

The developed application provides an opportunity to create a new database, edit an existing one and expand it with new elements. To operate the system, the reader must be first configured. The network address of the IF30, the type of labels and the connected antennas must be set.

The correctness of the configuration can be checked by pressing the "Test settings" button. Feedback will be received on the success of the connection on the application console. On the same page (Figure 7) it is the opportunity to test the label reading. The scanned label ID is also printed on the console. The contents of the console can be also deleted.

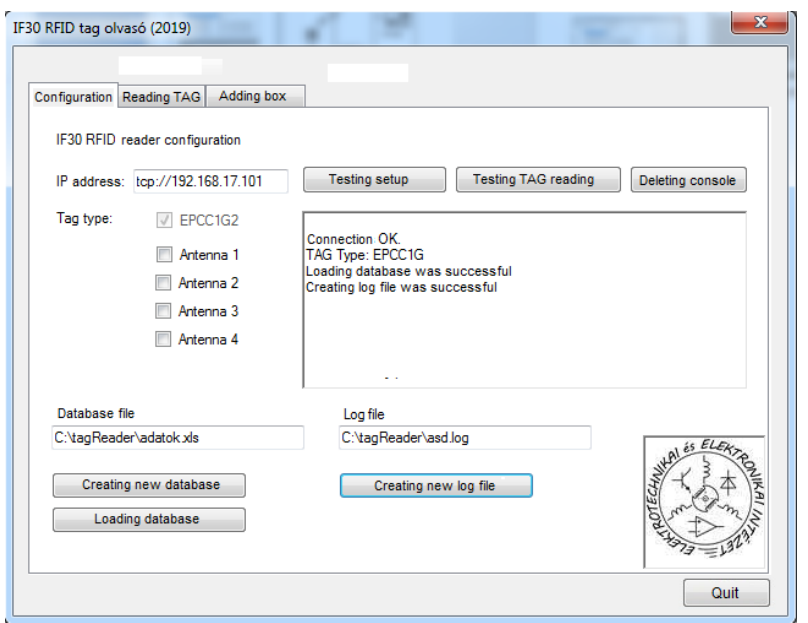

Fig. 7. Application configuration page

Clicking on the "TAG read" tab the main function of the application can be accessed. By clicking on the START button, the system continuously reads the IDs that come into its view. After the IDs are read, the evaluation is performed automatically (Figure 8). Three cases are possible. If the product composition is correct, "Everything is available!". If something is missing, then the missing IDs, if there are more products in it than necessary, then the unnecessary IDs, will be shown.

The application logs the timestamped events to a log file created from the database name for later processing.

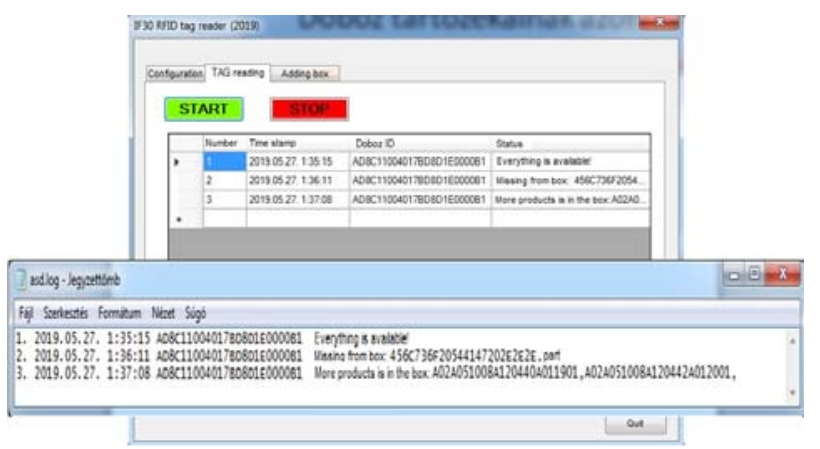

Fig. 8. Software developed to detect product mixing problems

\section{FUTURE RESEARCH DIRECTIONS}

As a possible future research direction, we would like to use RFID technology to integrate our laboratory and transform it to a cyber-physical logistics environment, where warehouse, storages, sorting and conveyor system, mobile robot, virtual reality module and a smart bin is integrated and used as an IoT solution. The computational processes can be realized as cloud, fog or edge computing and the users can access the whole system through the cloud or a web reporting application. Solving the future big data problems of the system, the computational operations regarding the planning and optimization of the system could be performed with a supercomputer.

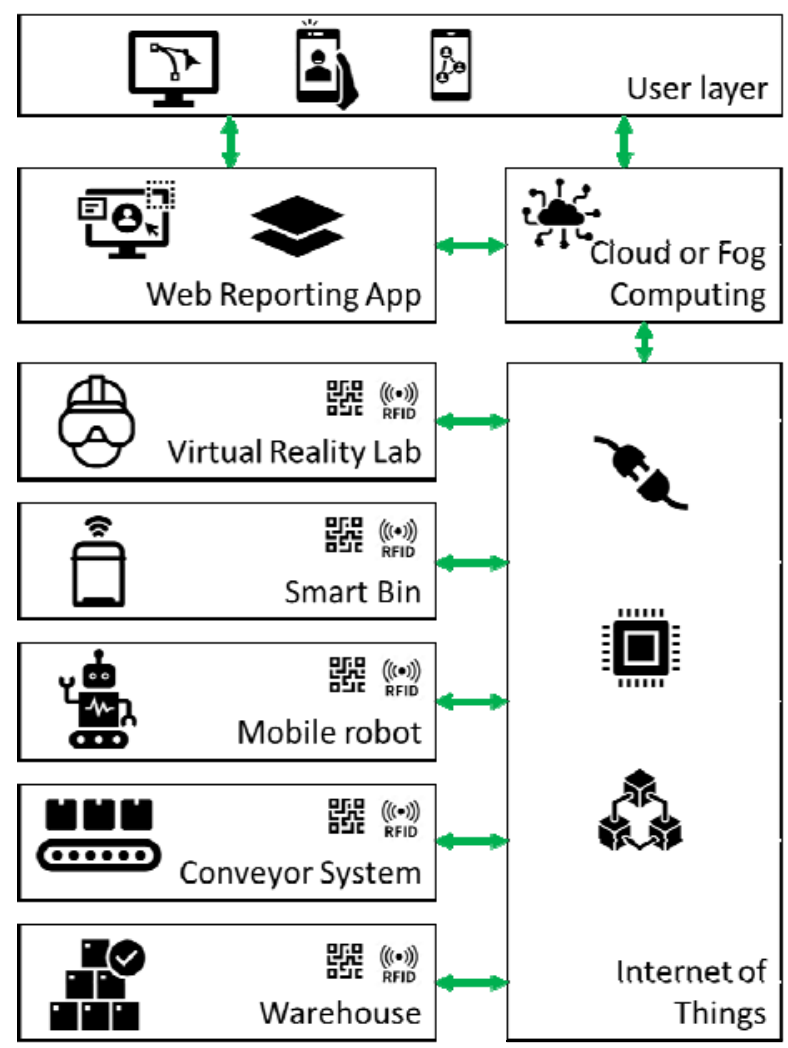

Fig. 9. Transformation of conventional logistics environment to cyber-physical system

\section{CONCLUSION}

In this paper, we have presented in detail a system developed to identify product mixing problems using 
industry 4.0 tools. Self-adhesive RFID tags were affixed to the unit load devices. Subsequently, multi-stage unit load formation was implemented using additional RFID tags. We recorded the binding of each product in an Excel format database. We have developed software that, on the one hand, controls our industrial IF30 RFID reader for product identification and, on the other hand, performs a product mixing detection test based on the scanned IDs and the database. The system constantly reads the IDs that come into its view. The developed system is able to detect the correct product composition and the unit loads containing missing or unnecessary products.

\section{REFERENCES}

[1] Radio-frequency identification. Source: https://en.wikipedia.org/wiki/Radio-

frequency_identification. Accessed: 22 October 2019.

[2] Nikitin, P., Parks, A., Smith, J. (2013). RFID-Vox: A Tribute to Leon Theremin. doi: 10.1007/978-14419-6166-2_16.

[3] Giusti, I., Cepolina, E.M., Cangialosi, E., Aquaro, D., Caroti, G., Piemonte, A. (2019) Mitigation of human error consequences in general cargo handler logistics: Impact of RFID implementation. Computers and Industrial Engineering 137:106038. doi: 10.1016/j.cie.2019.106038.

[4] Cao, X.H., Li, T., Wang, Q. (2019) RFID-based multi-attribute logistics information processing and anomaly mining in production logistics. International Journal of Production Research 57(17):5453-5466. 10.1080/00207543.2018.1526421.

[5] Lam, C.Y., Ip, W.H. (2019) An integrated logistics routing and scheduling network model with RFIDGPS data for supply chain management. Wireless Personal Communications 1056(3):803-817. doi: 10.1007/s11277-019-06122-6.

[6] Aboelmaged, M., Hashem, G. (2018) RFID application in patient and medical asset operations management: A technology, organizational and environmental (TOE) perspective into key enablers and impediments. International Journal of Medical Informatics 118:58-64. doi: 10.1016/j.ijmedinf.2018.07.009.

[7] Zeng, S.X., Xue, R., Chen, J.B. (2018) Research and design of medical logistics sorting system based on RFID. Basic \& Clinical Pharmacology \& Toxicology 122(2):11.

[8] Moatari-Kazerouni, A., Bendavid, Y. (2017) Improving logistics processes of surgical instruments: case of RFID technology. Business Process Management Journal 23(2):448-466. doi: 10.1108/BPMJ-06-2016-0127.

[9] Wang, L. (2018) Application of wireless sensor network and RFID monitoring system in airport logistics. International Journal of Online Engineering 14(1):89-103. doi: 10.3991/ijoe.v14i01.8058.

[10]Zhong, R.Y., Lan, S.L., Xu, C., Dai, Q.Y., Huang, G.Q. (2016) Visualization of RFID-enabled shopfloor logistics Big Data in Cloud Manufacturing. International Journal of Advanced Manufacturing Technology 84(1-4):5-16. doi: 10.1007/s00170-015-7702-1.

[11] Mejjaouli, S., Babiceanu, R.F. (2015) RFIDwireless sensor networks integration: Decision models and optimization of logistics systems operations. Journal of Manufacturing Systems 35: 234-245. doi: 10.1016/j.jmsy.2015.02.005.

[12] Yan, X.P., Li, J. (2019) Animal Intelligent Logistics Management Based on RFID Technology. Revista Cientifica-Facultad de Ciencias Veterinarias 29(6):1772-1780.

[13] Ramirez, J.J. (2012) Radio frequency identification (RFID) technology for academic, logistics and passenger transport applications. Ingenieria $\mathrm{e}$ Investigacion 32(3):58-65.

[14]Kang, Y.S., Kim, H., Lee, Y.H. (2018) Implementation of an RFID-based sequencingerror-proofing system for automotive manufacturing logistics. Applied Sciences-Basel 8(1):109. doi: 10.3390/app8010109.

[15] Low frequency cards. Source: Low Frequency Cards, http://www.futurlec.com/LF_Cards.shtml. Accessed: 12 September 2019

\section{Acknowledgement}

The article was carried out as part of the Erasmus + ProdLog and EFOP-3.6.1-16-2016-00011 projects.

Authors: R\&D Leader Lajos Tóth, Ten Pao Electronics Hungary Ltd., Bogáncs str. 4., 3508 Miskolc, Hungary, Phone.: +36 70684 8199, Professor Umetaliev Akylbek PhD., Kyrgyz State Technical University named I. Razzakov (KSTU), KyrgyzGerman Technical Institute, Department of Logistics, 66 Mir Avenue, Bishkek 720044, Kyrgyz Republic, Phone.: +0312 5451 60, Ass. Research Fellow Ákos Cservenák, Assoc. Professor Tamás Bányai PhD, Professor Béla Illés Dr. habil., Assoc. Professor, head of the Institute Tamás Péter PhD, University of Miskolc, Faculty of Mechanical Engineering and Informatics, Institute of Logistics, Egyetemváros, 3515 Miskolc, Hungary, Phone.: +36 46 565-111.

E-mail: mkt@tenpao.com akylbek.umetaliev@gmail.com cservenak.akos@uni-miskolc.hu alttamas@uni-miskolc.hu altilles@uni-miskolc.hu tamas.peter@uni-miskolc.hu 